\title{
Diagnostic and Genetical Aspects of Tuberous Sclerosis
}

\author{
N. C. NEVIN* and W. G. PEARCE \\ From the Medical Research Council, Population Genetics Research Unit, Old Road, Headington, Oxford
}

There have been many reviews of tuberous sclerosis (Critchley and Earl, 1932; Ross and Dickerson, 1943; Dawson, 1954; Reed, Nickel, and Campion, 1963; Paulson and Lyle, 1966; Lagos and Gomez, 1967). The classical features, epilepsy, mental retardation, and adenoma sebaceum, are found in most patients with tuberous sclerosis, while retinal tumours (phakomas), visceral tumours, skeletal lesions, and other cutaneous manifestations are noted less frequently. The complete syndrome is easily recognized in the older child and the adult, but in infancy and childhood the diagnosis may be difficult before the appearance of adenoma sebaceum. Convulsions, the most frequent presenting symptom, often begin in infancy and childhood, and may take the form of infantile spasms. Apart from adenoma sebaceum, a variety of skin manifestations occurs, shagreen plaques, subcutaneous fibromata, café-au-lait spots, periungual and subungual fibromata, cervical polypi or tags, and areas of depigmentation. Recently, Chao (1959) has called attention to depigmented areas of skin as the earliest skin lesion in tuberous sclerosis. In the course of treating 39 children with infantile spasms over a two-year period, Gold and Freeman (1965) found that of the children with areas of depigmented skin, 6 subsequently developed other manifestations of tuberous sclerosis. Crichton (1966) examined 174 children with infantile spasms, and of 11 with tuberous sclerosis, all had areas of depigmentation.

Early diagnosis of tuberous sclerosis would enable the paediatrician to provide a more realistic prognosis for the patient and would also greatly assist genetic counselling. In the course of a survey of tuberous sclerosis in the area of the Oxford Regional Hospital Board, we were able to examine 18 patients with tuberous sclerosis.

This paper describes the clinical features and

Received January 15, 1968.

* Present address: Department of Medical Statistics, Institute of Clinical Science, Grosvenor Road, Belfast BT12 6BJ, N. Ireland.

2 genetic data of these patients, with particular emphasis on the diagnostic criteria in infancy. A further 14 patients who were reported at necropsy to have died from tuberous sclerosis of the brain are also included in the study.

\section{Criteria for Clinical Diagnosis}

Typical cases exhibiting the complete syndrome present no difficulty in diagnosis, but where one or more of the major features are absent (formes frustes) or have not yet appeared, recognition is less easy.

Cases were therefore only included as suffering from tuberous sclerosis if they showed either: (a) adenoma sebaceum, or (b) retinal phakoma (astrocytic hamartoma).

\section{Present Investigation}

Persons with tuberous sclerosis living in the area of the Oxford Regional Hospital Board were ascertained from superintendents of mental institutions, consultant paediatricians, dermatologists, neurologists, neurosurgeons, pathologists, ophthalmologists, and from hospital records. Data for clinical and genetical analysis were obtained from the patients and relatives of 16 families. The relatives of only one index patient refused to take part in the investigation.

The ocular fundi were examined with full pupillary dilatation ( $1 \%$ homatropine or $1 \%$ cyclopentolate hydrochloride). In children and uncooperative mentally retarded adults, the examination was made under sedation, using for children, trimepazine syrup 4-6 mg. per $\mathrm{kg}$. body weight, and for adults tabs. quinalbarbitone or pentobarbitone sodium gr. 3-6. Where possible, a fundus photograph was taken using a Kowa fundus camera with Kodachrome-X film.

\section{Results}

Clinical Features. The clinical findings in the 18 patients with tuberous sclerosis are shown in Table I.

Skin and Mucosal Lesions. Adenoma sebaceum 273 was present in the naso-labial folds of $15(83 \%)$ 


\begin{tabular}{|c|c|c|c|c|c|c|c|c|c|}
\hline \multirow[b]{2}{*}{ Case } & \multirow[b]{2}{*}{ Sex } & \multirow[b]{2}{*}{$\begin{array}{c}\text { Age } \\
\text { When } \\
\text { Seen } \\
\text { (yr.) }\end{array}$} & \multicolumn{7}{|c|}{ Skin and Mucosal Lesions } \\
\hline & & & $\begin{array}{l}\text { Adenoma } \\
\text { Sebaceum }\end{array}$ & $\begin{array}{c}\text { Shagreen } \\
\text { Plaques }\end{array}$ & $\begin{array}{l}\text { Peri- or } \\
\text { Subungual } \\
\text { Fibromata }\end{array}$ & $\begin{array}{l}\text { Cervical } \\
\text { Polypi }\end{array}$ & $\begin{array}{c}\text { Depigmented } \\
\text { Areas }\end{array}$ & $\begin{array}{l}\text { Gingival } \\
\text { Fibroma }\end{array}$ & $\begin{array}{l}\text { Café-au-lait } \\
\text { Spots }\end{array}$ \\
\hline $\begin{array}{c}\text { Sporadic } \\
\text { NN4 } \\
\text { NN14 } \\
\text { NN13 } \\
\text { NN3 } \\
\text { NN12 } \\
\text { NN11 } \\
\text { NN7 } \\
\text { NN6 } \\
\text { NN10 } \\
\text { NN8 } \\
\text { NN20 } \\
\text { NN5 }\end{array}$ & $\begin{array}{l}M \\
\mathbf{F} \\
\mathbf{M} \\
\mathrm{M} \\
\mathrm{F} \\
\mathbf{M} \\
\mathbf{M} \\
\mathbf{M} \\
\mathbf{F} \\
\mathbf{M} \\
\mathbf{M} \\
\mathbf{F}\end{array}$ & $\begin{array}{r}21 \\
5 \\
18 \\
20 \\
22 \\
13 \\
21 \\
4 \\
21 \\
20 \\
3 \\
34\end{array}$ & $\begin{array}{l}+ \\
+ \\
+ \\
+ \\
+ \\
+ \\
+ \\
+ \\
+ \\
+ \\
+\end{array}$ & $\begin{array}{l}+ \\
+ \\
+ \\
+ \\
+ \\
+ \\
+ \\
+ \\
+ \\
+ \\
+ \\
+\end{array}$ & $\begin{array}{l}\overline{-} \\
\overline{-} \\
+ \\
+ \\
\overline{+} \\
\overline{+} \\
\overline{+} \\
\overline{+}\end{array}$ & $\begin{array}{l}+ \\
- \\
- \\
+ \\
\overline{+} \\
+ \\
\overline{-} \\
- \\
- \\
\overline{+}\end{array}$ & $\begin{array}{l}+ \\
+ \\
+ \\
- \\
- \\
+ \\
+ \\
+ \\
- \\
+ \\
+ \\
-\end{array}$ & $\begin{array}{l}\overline{-} \\
\overline{-} \\
\overline{+} \\
\overline{+} \\
\overline{-} \\
\overline{+} \\
\overline{-} \\
\overline{-} \\
-\end{array}$ & $\begin{array}{l}\overline{-} \\
\overline{+} \\
\overline{+} \\
+ \\
\overline{+} \\
\overline{+} \\
\overline{-} \\
\overline{-}\end{array}$ \\
\hline$\underset{\text { NN1 }}{\text { Familial }}$ & $\mathbf{M}$ & 19 & + & + & - & - & - & + & - \\
\hline $\begin{array}{l}\text { NN21 } \\
\text { NN22 } \\
\text { NN22 } \\
\text { NN9 } \\
\text { NN17 }\end{array}$ & $\begin{array}{l}M \\
F \\
F \\
F \\
M\end{array}$ & $\begin{array}{r}28 \\
2 \\
1 \\
59 \\
34\end{array}$ & $\begin{array}{l}+ \\
- \\
\overline{+} \\
+\end{array}$ & $\begin{array}{l}+ \\
- \\
+ \\
+\end{array}$ & $\begin{array}{l}- \\
\overline{-} \\
\overline{+} \\
+\end{array}$ & $\begin{array}{l}+ \\
- \\
- \\
+\end{array}$ & $\begin{array}{l}+ \\
+ \\
+ \\
- \\
-\end{array}$ & $\begin{array}{l}- \\
- \\
- \\
-\end{array}$ & $\begin{array}{l}- \\
- \\
\bar{t}\end{array}$ \\
\hline \multicolumn{3}{|c|}{ Total No. of Cases (18) } & $15(83 \cdot 3 \%)$ & $15(83 \cdot 3 \%)$ & $7(39 \cdot 4 \%)$ & $7(39 \cdot 4 \%)$ & $11(61 \cdot 1 \%)$ & $4(22 \cdot 2 \%)$ & $5(27 \cdot 7 \%)$ \\
\hline
\end{tabular}

P.M, petit mal; GM, grand mal; IS, infantile spasms.

patients; 13 patients older than 12 years had multiple lesions, while the 2 youngest patients aged 4 and 5 had at least one identifiable adenoma sebaceum. The 3 patients lacking adenoma sebaceum were aged 1 year, 2 years, and 3 years.

Shagreen patches were also found in $15(83 \%)$ patients. These lesions were located in the lumbar region. All affected individuals over 12 years of age, and 2 children aged 3 years and 5 years, had shagreen lesions, while the 3 without shagreen patches were aged 1 year, 2 years, and 4 years.

Areas of skin depigmentation were present in 11 ( $61 \%)$ patients, including the 5 children in the series. Unlike the shagreen patches, no predilection for a particular region was observed. In several patients, these white areas had been noted at birth, but in others recognition was delayed until they were emphasized by their inability to tan.

Periungual and subungual fibromata were observed in $7(39 \%)$ patients, cervical polypi or tags in $7(39 \%)$, café-au-lait spots in $5(27 \%)$, gingival tumours in $4(22 \%)$, subcutaneous fibromata in 3 $(16 \%)$, and a scalp tumour in one patient.

Convulsions and Mental Retardation. Fifteen $(83 \%)$ patients presented with convulsions. Ten with grand mal, petit mal, or both, were over the age of 12 , whereas the convulsions in the remainder, who were aged 1 to 5 years, took the form of infantile spasms. In only 3 patients was there no history of convulsions.
Mental retardation was present in $11(61 \%)$ 요 patients, and all had associated convulsions. Among the 7 patients with normal intelligence, 6 were in regular employment and one was residen in an epileptic colony.

Ocular Lesions. Retinal tumours (phakomas) were found in $13(76 \%)$ of 17 patients. The remaining patient had had a bilateral enucleation in infancy for suspected retinoblastoma.

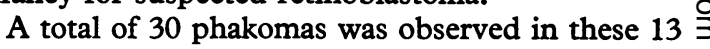
patients. Their frequency in one or both eyes is included in Table I. The majority of phakomas (20) were white in colour, well demarcated, and projected from the retina with an irregular nodular surface. The minority (10) were greyish-white in colour, less well outlined, and tended to fade into the surrounding retina. They had a smooth regular surface and did not project forward from the retina. In the 5 children, the projecting variety of tumour appeared virtually colourless, with a translucent veil-like sheen through which the retina was indistinctly visualized. A fine retinal vessel was N noted to pass over the surface of 3 tumours, but the remainder appeared totally avascular.

Associated ocular findings may be considered in 3 groups.

(1) As part of the clinical picture of tuberous sclerosis. These included areas of depigmented retina observed in 2 patients and a small retinal plaque found in a further patient. This latter . 定 $\overline{3}$ (1) 을 D 


\begin{tabular}{|c|c|c|c|c|c|c|}
\hline \multirow{3}{*}{$\begin{array}{l}\text { Type of } \\
\text { Convulsions }\end{array}$} & \multirow{3}{*}{$\begin{array}{l}\text { Mental } \\
\text { Retardation }\end{array}$} & \multicolumn{3}{|c|}{ Ocular Lesions } & \multirow{3}{*}{ Community Status } & \multirow{3}{*}{ Case } \\
\hline & & \multicolumn{2}{|c|}{ Phakomas } & \multirow{2}{*}{ Others } & & \\
\hline & & Right & Left & & & \\
\hline $\begin{array}{c}\text { PM } \\
\text { IS } \\
\text { PM } \\
\text { PM } \\
\text { GM } \\
\text { PM } \\
\text { GM+PM } \\
\text { IS } \\
\text { GM+PM } \\
\text { IS } \\
\text { GM }\end{array}$ & $\begin{array}{l}- \\
+ \\
+ \\
+ \\
+ \\
+ \\
+ \\
+ \\
- \\
+\end{array}$ & $\begin{array}{l}\overline{+} \\
+(2) \\
\text { Bilateral } \\
- \\
+(2) \\
+(1) \\
+(2) \\
+(2) \\
- \\
+(1) \\
+(1) \\
+\end{array}$ & $\begin{array}{l}+(1) \\
- \\
\text { cleation } \\
\overline{+} \\
+(2) \\
+(2) \\
+(1) \\
+(2) \\
\overline{-} \\
+(1) \\
+(2)\end{array}$ & $\begin{array}{l}\text { Divergent squint-left } \\
\text { Bilateral optic atrophy } \\
\text { Optic atrophy - left } \\
= \\
=\end{array}$ & $\begin{array}{l}\text { Working } \\
\text { Home with intermittent hospitalization } \\
\text { Institutionalized } \\
\text { Institutionalized } \\
\text { Institutionalized } \\
\text { Institutionalized } \\
\text { Epileptic colony } \\
\text { At home with intermittent hospitalization } \\
\text { Working } \\
\text { Working } \\
\text { At home with intermittent hospitalization } \\
\text { Institutionalized }\end{array}$ & $\begin{array}{l}\text { Sporadic } \\
\text { NN4 } \\
\text { NN14 } \\
\text { NN13 } \\
\text { NN3 } \\
\text { NN12 } \\
\text { NN11 } \\
\text { NN7 } \\
\text { NN6 } \\
\text { NN10 } \\
\text { NN8 } \\
\text { NN20 } \\
\text { NN5 }\end{array}$ \\
\hline GM & + & $+(1)$ & - & $\begin{array}{l}\text { Coloboma iris and choroid- } \\
\text { right }\end{array}$ & Institutionalized & $\begin{array}{l}\text { Familial } \\
\text { NN1 }\end{array}$ \\
\hline$\overline{\text { IS }}$ & $\begin{array}{l}\overline{+} \\
+ \\
-\end{array}$ & $\begin{array}{l}\overline{+} \\
\overline{-} \\
-\end{array}$ & $\begin{array}{l}+(5) \\
\overline{+}(1) \\
-\end{array}$ & $\begin{array}{l}\text { Bilateral depigmented patches } \\
\text { Retinal plaque-right } \\
\text { Bilateral depigmented patches }\end{array}$ & $\begin{array}{l}\text { Working } \\
\text { At home with intermittent hospitalization } \\
\text { At home with intermittent hospitalization } \\
\text { Working } \\
\text { Working }\end{array}$ & $\begin{array}{l}\text { NN21 } \\
\text { NN22 } \\
\text { NN22 } \\
\text { NN9 } \\
\text { NN17 }\end{array}$ \\
\hline $15(83 \cdot 3 \%)$ & $11(61 \cdot 1 \%)$ & $13(7$ & & & & \\
\hline
\end{tabular}

lesion was similar to what François and Deweer (1952) called an atypical coloboma of choroid. These lesions alone were not sufficient for a diagnosis of tuberous sclerosis.

(2) As complications of tuberous sclerosis. The optic atrophy found in 2 patients was probably secondary to phakomas in the optic nerves. In one patient, small tumours were visible within the physiological optic cup.

(3) Coincidental to tuberous sclerosis. One patient had a typical coloboma of the choroid and iris, and one had a divergent squint.

Community Status. The 18 patients form 3 quite distinct groups with regard to their social position in the community. Group I-adults of normal intelligence in regular employment (6); Group IIadults requiring continuous institutional care (7); Group $I I I$-children with mental retardation living at home but requiring intermittent hospitalization (5). The frequency of the cutaneous, cerebral, and ocular manifestations in each group is shown in Table II.
Necropsy Cases. A survey of necropsy records from 1941 to 1966 inclusive revealed 14 cases of tuberous sclerosis (Table III). The mean age at death was 23.80 years (SD 21.74). All these cases presented with convulsions save one infant, where the onset was characterized by attacks of cyanosis, the necropsy revealing a rhabdomyoma of the heart, as well as tuberous sclerosis of the brain. The latter finding was present in the remaining 13 patients, though in the majority tuberous sclerosis had not been diagnosed or suspected, as the characteristic skin lesions were either absent or so minimal that they were not detected. These families were traced and all first degree relatives were visited and examined. Six cases (A5, 6, 8, 9, 10, and 12) were born outside the area and 2 cases (A4 and A8) were from family NN1. Therefore within the area of the Oxford Regional Hospital Board there were 6 deceased sporadic cases.

Genetical Findings Among Living Cases. From all sources, 20 subjects were ascertained as.

TABLE II

FREQUENCY OF MAJOR FEATURES OF TUBEROUS SCLEROSIS ACCORDING TO STATUS IN COMMUNITY

\begin{tabular}{l|c|c|c|c|c|c}
\hline & No. & $\begin{array}{c}\text { Adenoma } \\
\text { Sebaceum }\end{array}$ & $\begin{array}{c}\text { Depigmented } \\
\text { Areas }\end{array}$ & Convulsions & $\begin{array}{c}\text { Mental } \\
\text { Retardation }\end{array}$ & $\begin{array}{c}\text { Retinal } \\
\text { Tumours }\end{array}$ \\
\hline Group I (employed) & 6 & 6 & 3 & 3 & 0 & 3 \\
Group II (institutionalized) & 7 & 7 & 3 & 7 & 6 & $5^{\star}$ \\
Group III (children) & 5 & 2 & 5 & 5 & 5 & 5 \\
\hline
\end{tabular}

\footnotetext{
* Excludes patient with bilateral enucleation.
} 
TABLE III

NECROPSY FINDINGS IN 14 PATIENTS

\begin{tabular}{|c|c|c|c|c|c|}
\hline Case & Sex & $\begin{array}{c}\text { Year of } \\
\text { Birth }\end{array}$ & $\begin{array}{c}\text { Age at } \\
\text { Death (yr.) }\end{array}$ & Symptoms and Signs & Necropsy Findings \\
\hline $\begin{array}{l}\text { A1 } \\
\text { A2 }\end{array}$ & $\begin{array}{l}\mathbf{F} \\
\mathbf{F}\end{array}$ & $\begin{array}{l}1955 \\
1959\end{array}$ & $\begin{array}{l}3 \text { wk. } \\
2 \mathrm{mth} \text {. }\end{array}$ & $\begin{array}{l}\text { Talipes and spasticity } \\
\text { Pseudosclerema neonatorum; calcinosis } \\
\text { universalis }\end{array}$ & $\begin{array}{l}\text { Tuberous sclerosis, brain } \\
\text { Tuberous sclerosis, brain; } \\
\text { rhabdomyoma heart }\end{array}$ \\
\hline $\begin{array}{l}\text { A3 } \\
\text { A4 }\end{array}$ & $\stackrel{\mathrm{M}}{\mathrm{F}}$ & $\begin{array}{l}1958 \\
1956\end{array}$ & $\begin{array}{l}18 \mathrm{mth} \text {. } \\
\text { Stillborn }\end{array}$ & Enlarged penis and testes; pubic hair; acne & $\begin{array}{l}\text { Tuberous sclerosis, brain } \\
\text { Tuberous sclerosis, brain; } \\
\text { rhabdomyoma heart; renal cysts }\end{array}$ \\
\hline A5 & $\mathbf{M}$ & 1921 & 27 & $\begin{array}{l}\text { Adenoma sebaceum; mental retardation; } \\
\text { shagreen patches; phakoma retina }\end{array}$ & Tuberous sclerosis, brain \\
\hline $\begin{array}{l}\text { A6 } \\
\text { A7 } \\
\text { A8 } \\
\text { A9 } \\
\text { A10 }\end{array}$ & $\begin{array}{l}\mathbf{F} \\
\mathbf{M} \\
\mathbf{F} \\
\mathbf{F}\end{array}$ & $\begin{array}{l}1930 \\
1938 \\
1920 \\
1921 \\
1908\end{array}$ & $\begin{array}{l}33 \\
24 \\
38 \\
44 \\
54\end{array}$ & $\begin{array}{l}\text { Adenoma sebaceum; mental retardation } \\
\text { Adenoma sebaceum; mental retardation } \\
\text { Status epilepticus } \\
\text { Signs of brain tumour } \\
\text { Signs of brain tumour }\end{array}$ & $\begin{array}{l}\text { Tuberous sclerosis, brain } \\
\text { Tuberous sclerosis, brain } \\
\text { Tuberous sclerosis, brain } \\
\text { Tuberous sclerosis, brain } \\
\text { Paraventricular tumours of tuberous } \\
\text { sclerosis }\end{array}$ \\
\hline $\begin{array}{l}\text { A11 } \\
\text { A12 } \\
\text { A13 } \\
\text { A14 }\end{array}$ & $\begin{array}{l}\mathrm{M} \\
\mathrm{F} \\
\mathrm{F}\end{array}$ & $\begin{array}{l}1938 \\
1949 \\
1956 \\
1882\end{array}$ & $\begin{array}{l}19 \\
14 \\
10 \\
69\end{array}$ & $\begin{array}{l}\text { Immature personality } \\
\text { Infantile hemiplegia (L); optic atrophy } \\
\text { Mental retardation } \\
\text { Road accident; low intelligence }\end{array}$ & $\begin{array}{l}\text { Tuberous sclerosis, brain } \\
\text { Tuberous sclerosis, brain } \\
\text { Tuberous sclerosis, brain } \\
\text { Tuberous sclerosis, brain }\end{array}$ \\
\hline
\end{tabular}

affected and the diagnosis was confirmed in 16 . Investigation of the living relatives yielded a further 2 affected subjects. In 4 families (Fig. and Appendix) the pattern of inheritance was characteristic of a dominant trait, while in the remaining 12 families only one member in each was affected, and these were considered to represent 'sporadic' cases. There were 4 female and 8 male sporadic cases whose ages ranged from 3 to 34 years (mean 16.83 SD 9.07 years). The patients with a family history of tuberous sclerosis consisted of 3 males and 3 females whose ages ranged from 1 to 59 years (mean 23.83 SD 21.81 years).

Parental Age and Birth Order of Sporadic Cases. Parental age and birth order were obtained in 11 of the 12 living sporadic cases. The parents of the remaining case refused to co-operate in the investigation. The mean birth rank was 2.36 (SD 1.56). The maternal age at the birth of the sporadic case was 28.27 years (SD $5 \cdot 16$ ). The mean maternal age for the general population was 27.65 (SD 5.84) years (Blank, 1960). The paternal age at the birth of the sporadic case was 32.91 years (SD 5.01), compared with the mean paternal age of 31.04 years (SD 6.79) for the general population (Blank, 1960). The difference between the mean parental ages was +4.64 years.

Prevalence of Ascertained Living Cases in a Population. Eighteen living affected individuals were ascertained in the area of the Oxford Regional Hospital Board which has a population of about $1,800,000$. The crude prevalence of ascertained cases was therefore about $10 \times 10^{-6}$. Of these 18 living cases, 12 were sporadic so that the prevalence of ascertained sporadic living casas was about $7 \times 10^{-6}$. This must be regarded as a minimal estimate of the true prevalance.

Frequency of Sporadic Cases in a Series of Births. Considering together the sporadic living cases and those ascertained via necropsy records, as will be seen from Tables I and III, 18 were born between 1882 and 1964 . Ignoring the two earlies born, there were 16 births of sporadic cases between 1938 and 1964 . Between 1938 and 1966 there were about 756,000 live births in the area, so that the frequency of sporadic cases in live births was about $21 \times 10^{-6}$.

Many children with tuberous sclerosis must have been born and died since 1938 without being ascertained either as living or from necropsy records, so that again this is the lower limit for an estimate of birth frequency.

It will be noted that the estimated prevalence of living sporadic cases $\left(7 \times 10^{-6}\right)$ is only one-third of the estimate (which is minimal) of the frequency at birth $\left(21 \times 10^{-6}\right)$. This is what would be expected by reason of high childhood mortality from tuberous sclerosis; but in view of the inexact nature of both estimates, no quantitative conclusions can be drawn.

Mutation Rate. It seems reasonable to suppose that a high proportion of all sporadic cases are mutants having received a fresh mutation that arose in the germ cells of a parent. Certainly this is so in respect of the cases mentioned where relatives have been examined. On such an assumption a minimal direct estimate of the mutation rate is $\frac{1}{2}$ $\left(21 \times 10^{-6}\right)=10.5 \times 10^{-6}$ per gene per generation. 


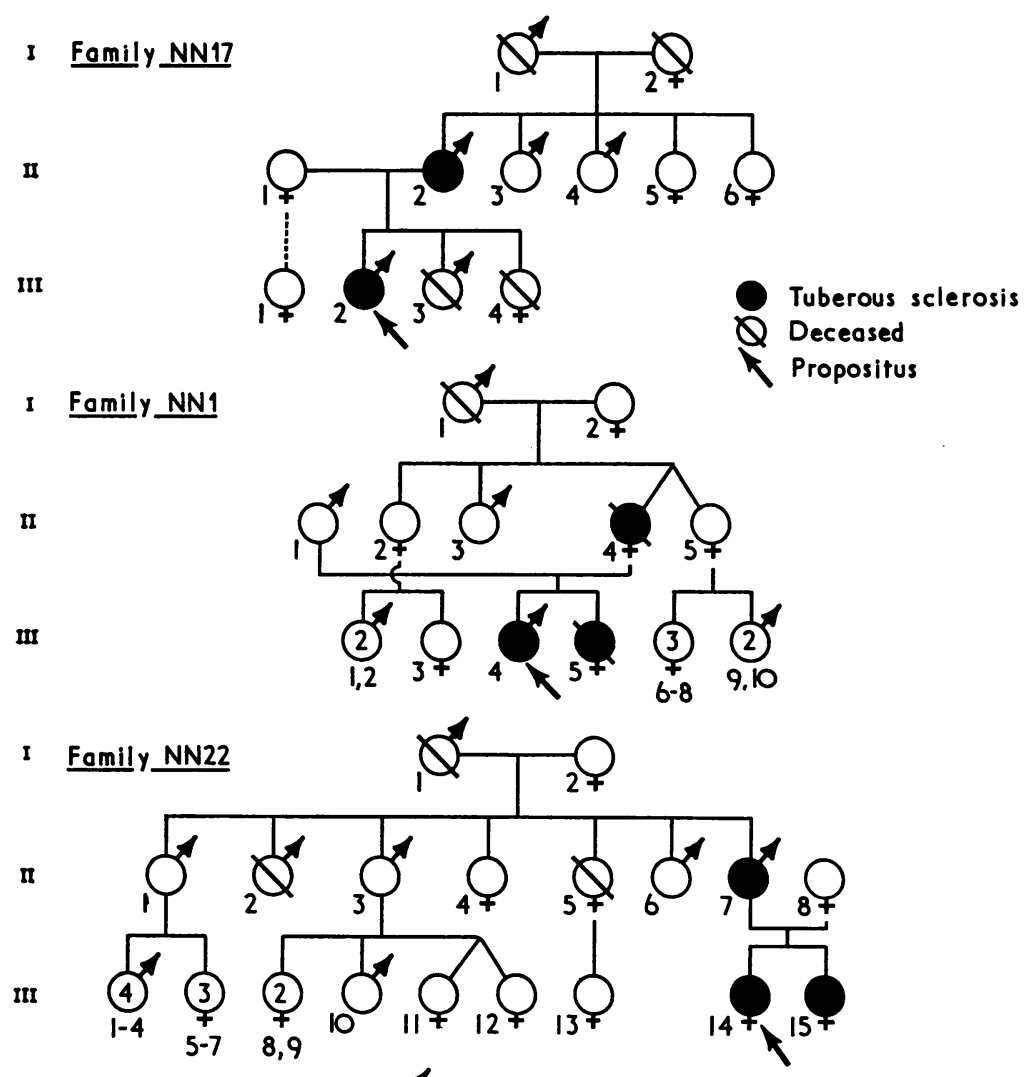

1 Family NN9

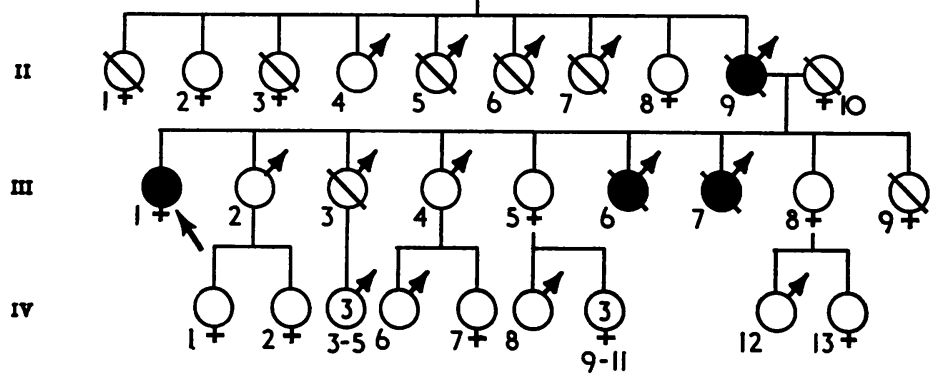

FIG. Pedigrees of familial cases of tuberous sclerosis.

\section{Discussion}

Adenoma sebaceum and shagreen plaques were the most frequent cutaneous manifestations of tuberous sclerosis, being present in all affected subjects over 5 years of age. Their absence in infants and young children has always made diagnosis difficult. The present investigation emphasizes that other cutaneous lesions may be present from an early age, in particular areas of skin depigmenta- tion. This observation confirms that of Chao (1959), Gold and Freeman (1965), and Crichton (1966).

Surprisingly, the next most frequent manifestation of tuberous sclerosis has been the high percentage $(76 \%)$ of patients with retinal tumours (phakomas). One additional patient (NN13) had a bilateral enucleation in infancy for suspected retinoblastoma which could not be confirmed 
histologically. The ophthalmoscopic appearance of early retinoblastoma and phakoma is often similar, as textbook illustrations demonstrate (Walsh, 1957; Waardenburg, Franceschetti, and Klein, 1963; Reese, 1963). Tuberous sclerosis, however, is not usually included among the pseudogliomatous lesions to be differentiated from retinoblastoma (Duke-Elder, 1964; Reese, 1963). There have been cases of infants' eyes enucleated for retinoblastoma which have shown the histological characteristics of an astrocytic hamartoma of the retina (Hogan and Zimmerman, 1962), and only later have the patients developed other manifestations of tuberous sclerosis (McLean, 1956; Reed et al., 1963). This may have been the sequence in the present case.

The incidence of phakomas in the present series is the highest since Van der Hoeve (1920) described retinal tumours in each of 6 patients with tuberous sclerosis. The incidence of phakomas varies with the investigator: $3.5 \%$ (Critchley and Earl, 1932); $12.5 \%$ (Chao, 1959); 30\% (Hall, 1946); $43 \%$ (Gold and Freeman, 1965); 47\% (Reed et al., 1963); and $53 \%$ (Lagos and Gomez, 1967). We have been able to achieve satisfactory fundus examination of unco-operative patients with dilatation of the pupils and sedation as outlined above. This procedure of examination under anaesthesia is particularly valuable in young children in whom the diagnosis has not been made.

In the present study, of the 5 children with infantile spasms and areas of skin depigmentation, 2 had adenoma sebaceum and had already been diagnosed as tuberous sclerosis. Before the appearance of the adenoma sebaceum, however, these children had been considered autistic or epileptic with mental retardation. Similar diagnoses had been given to the other 3 children with infantile spasms. The diagnosis of tuberous sclerosis was made in all by finding retinal tumours (phakomas). We feel that the association of areas of skin depigmentation and infantile spasms in children strongly suggests the possibility of tuberous sclerosis and is an indication for examination of the ocular fundi.

Patients in the present study were segregated into 3 groups on the basis of community status (Table II). The 5 children (Group III) with infantile spasms and mental retardation will eventually require continuous institutional care similar to the 7 patients in Group II. These patients had convulsions and all but one were mentally retarded. When the severity of tuberous sclerosis referred to the degree of mental impairment, the chances of finding a retinal tumour were very high ( 9 out of 10 patients). Retinal tumours (phakomas) were present in half the 6 patients of
Group I, in whom there was no mental retardation. $\frac{1}{2}$

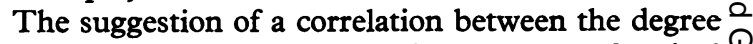
of mental impairment and the presence of retinal $\mathbb{\Phi}$

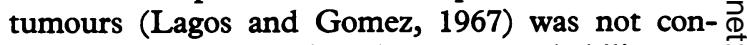
firmed statistically using the exact probability test $(p=0 \cdot 1181)$.

Tuberous sclerosis is inherited as an autosomal dominant trait (Gunter and Penrose, 1935; Borberg, 흘 1951). In the present study, the disorder was ob- $\frac{\bar{T}}{7}$ served in 2 generations in 4 families. Examination $\stackrel{\mathbb{\complement}}{\Omega}$ of the relatives in 12 families failed to reveal further cases of tuberous sclerosis and these affected patients $\overrightarrow{0}$ were considered to be sporadic. The true inci-? dence of tuberous sclerosis is difficult to estimate $\vec{\omega}$ because of the varying manifestations and the diffi- $\stackrel{\rho}{S}$ culty of ascertaining formes frustes. We have estimated a minimal frequency of the trait for the ir population of the area of the Oxford Regional $\rightarrow$ Hospital Board to be 1 in 100,000. Dawson (1954) N estimated an incidence of 1 in 300,000 for England. $\omega$ Patients with incomplete forms of the disease are probably as frequent as the complete triad, and $\vec{r}$ thus Dawson (1954) suggested that the frequency $\mathbb{D}$ of tuberous sclerosis is probably about 1 in 150,000 $\Phi$ persons. Gunter and Penrose (1935) found the $\bar{\sigma}$ incidence of tuberous sclerosis in hospitals for $\stackrel{\mathbb{C}}{-}$ mental defectives at 1 in 300 , and as the incidence $\vec{\varphi}$ of mental deficiency in the population is $1 \%$, est 8 \& mated the incidence of severe cases in the popula tion to be at 1 in 30,000. In Northern Ireland the⿳⺈. incidence of tuberous sclerosis was estimated at 1 i 150,000 (Stevenson and Fisher, 1956).

As most severely affected patients with tuberous sclerosis do not reproduce, the mutation rate must be adequate to maintain a constant proportion of tuberous sclerosis in the community if the condition is not to be eradicated. The assumption, therefore, that most sporadic cases are due to mutation is not unreasonable. We have calculated a minimal mutation rate of 10.5 per million genes per generation. Gunter and Penrose (1935) estimated it to be 8 per million genes per generation.

Advanced parental age has been known to be a feature of conditions such as achondroplasia (Stevenson, 1957), Marfan's syndrome (Lynas, 1958), and acrocephalosyndactyly (Blank, 1960). In sporadic cases of tuberous sclerosis, neurofibromatosis, and retinoblastoma, parental ages are slightly raised above the population average but the difference is barely significant statistically when all groups are pooled (Table 6, Penrose, 1961). In the Northern Ireland survey (Stevenson and Fisher, 1956) the parental ages of the sporadic cases seemed high. The number of cases in the present study is not sufficient to form any conclusions. 


\section{Summary}

An attempt has been made to ascertain all cases of tuberous sclerosis in the area of the Oxford Regional Hospital Board. A total of 32 patients was found, and of these 18 were alive at the time of the study.

Tuberous sclerosis was inherited as a regular autosomal dominant trait affecting 6 living and 5 dead members of 4 families over 2 generations. Twelve living patients were the only affected subject in the remaining 12 families and were considered to be 'sporadic' cases. Necropsy records revealed a further 14 patients, of whom 6 were both sporadic and born within the region. The minimal incidence of tuberous sclerosis in the area was 1 in 100,000 persons. The rate of mutation at the tuberous sclerosis locus was estimated to be at least $10.5 \times 10^{-6}$ per gene per generation.

Clinical examination of affected subjects revealed a wide range of cutaneous manifestations. Adenoma sebaceum was present in $15(83 \%)$ patients, shagreen plaques in $15(83 \%)$, depigmented areas in $11(61 \%)$, cervical tags or polypi in $7(39 \%)$, periungual and subungual fibromata in 7 $(39 \%)$, café-au-lait spots in $5(28 \%)$, and gingival fibromata in $4(22 \%)$. Mental retardation was a feature in $11(61 \%)$ patients and convulsions in 15 $(83 \%)$. Retinal tumours (phakomas) were observed in 13 out of 17 patients $(76 \%)$.

Five children with infantile spasms had multiple depigmented patches and retinal tumours (phakomas). The suspicion that infantile spasms with multiple depigmented patches is often an early manifestation of tuberous sclerosis has been confirmed, and the finding of retinal tumours (phakomas) in all of these cases has enabled a definitive diagnosis to be made. It is suggested that a fundus examination should be a routine procedure in all cases of infantile spasms associated with skin depigmentation.

We are particularly indebted to Dr. H. O. Phillipson of Manor House Hospital, Aylesbury, Bucks, and Dr. B. D. Bower of the Radcliffe Infirmary, Oxford, who provided us with the facilities for examining the children under their care, and without whose active assistance and co-operation this work would have been incomplete. We are also grateful to the superintendents of the hospitals for mentally retarded patients and to the consultant paediatricians, dermatologists, neurologists, neurosurgeons, and pathologists of the Oxford Regional Hospital Board for referring their patients and allowing access to their records. We would finally like to thank Dr. A. C. Stevenson, Director of the Population Genetics Research Unit, for initiating the study, and for his advice and criticism in the preparation of this paper.
REFBRENCES

Blank, C. E. (1960). Apert's syndrome (a type of acrocephalosyndactyly)-observations on a British series of thirty-nine cases. Ann. hum. Genet., 24, 151.

Borberg, A. (1951). Clinical and genetic investigations into tuberous sclerosis and Recklinghausen's neurofibromatosis: Contribution to elucidation of interrelationship and eugenics of syndromes. Acta psychiat. scand., Suppl. 71.

Chao, D. H. C. (1959). Congenital neurocutaneous syndromes in childhood: II Tuberous sclerosis. F. Pediat., 55, 447.

Crichton, J. U. (1966). Infantile spasms and skin anomalies. Develop. Med. Child Neurol., 8, 273.

Critchley, M., and Earl, C. J. C. (1932). Tuberose sclerosis and allied conditions. Brain, 55, 311.

Dawson, J. (1954). Pulmonary tuberous sclerosis and its relationship to other forms of the disease. Quart. F. Med., 23, 113.

Duke-Elder, S. (1964). System of Ophthalmology, vol. III normal and abnormal development, pt. 2 congenital deformities, p. 793. Kimpton, London.

François, J., and Deweer, J. P. (1952). Sclérose tubéreuse cérébrale de Bourneville. Ophthalmologica (Basel), 124, 321.

Gold, A. P., and Freeman, J. M. (1965). Depigmented nevi: The earliest sign of tuberous sclerosis. Pediatrics, $35,1003$.

Gunter, M., and Penrose, L. S. (1935). Genetics of epiloia. $\mathfrak{F}$. Genet., 31, 413.

Hall, G. S. (1946). The ocular manifestations of tuberous sclerosis. Quart. F. Med., 15, 209.

Hogan, M. J., and Zimmerman, L. E. (1962). Ophthalmic Pathology, 2nd ed., p. 527. W. B. Saunders, Philadelphia.

Lagos, J. C., and Gomez, M. R. (1967). Tuberous sclerosis: Reappraisal of a clinical entity. Mayo Clin. Proc., 42, 26.

Lynas, M. A. (1958). Marfan's syndrome in Northern Ireland: An account of thirteen families. Ann. hum. Genet., 22, 289.

McLean, J. M. (1956). Glial tumours of the retina in relation to tuberous sclerosis. Amer. F. Ophthal., 41, 428.

Paulson, G. W., and Lyle, C. B. (1966). Tuberous sclerosis. Develop. Med. Child Neurol., 8, 571 .

Penrose, L. S. (1961). Recent Advances in Human Genetics, p. 14. Ed. by L. S. Penrose and H. L. Brown. J. \& A. Churchill, London.

Reed, W. B., Nickel, W. R., and Campion, G. (1963). Internal manifestations of tuberous sclerosis. Arch. Derm., 87, 715.

Reese, A. B. (1963). Tumours of the Eye, 2nd ed., pp. 112 and 176. Harper \& Row, New York.

Ross, A. T., and Dickerson, W. W. (1943). Tuberous sclerosis. Arch. Neurol. Psychiat. (Chic.), 50, 233.

Stevenson, A. C. (1957). Achondroplasia: an account of the condition in Northern Ireland. Amer. F. hum. Genet., 9, 81.

, and Fisher, O. D. (1956). Frequency of epiloia in Northern Ireland. Brit. F. prev. soc. Med., 10, 134.

Van der Hoeve, J. (1920). Eye symptoms in tuberous sclerosis of the brain. Trans. ophthal. Soc. U. K., 40, 329.

Waardenburg, P. J., Franceschetti, A., and Klein, D. (1963). Genetics and Ophthalmology, vol. 2, p. $1335 . \quad$ Blackwell, Ox ford. Walsh, F. B. (1957). Clinical Neuro-opthalmology, 2nd ed., p. 937. Williams and Wilkins, Baltimore.

\section{Appendix}

\section{Clinical Details of Familial Cases of Tuberous Sclerosis}

The pedigrees of the following families are displayed in the Figure.

(a) Family NN17. The propositus (III.2), a man aged 34 years, was 10 years old before his speech was intelligible. The first grand mal attack occurred when he was 2 and adenoma sebaceum when he was 15 . There were periungual fibromata of the fingers, shagreen plaques in the lumbosacral region, cervical skin tags, and several café-au-lait spots. The ocular fundi showed well-demarcated depigmented areas but no phakomas. 
Radiographs of the skull showed intracranial calcification. Intravenous pyelogram was normal.

The mother (II.1) and a half-sister (III.1) were normal. A brother (III.3) died aged 14 months with scarlet fever and a sister (III.4) with jaundice at 1 week. The father's (II.2) only manifestation of tuberous sclerosis was adenoma sebaceum, but neither he nor his brothers and sisters were available for examination.

(b) Family NN1. The propositus (III.4), a youth of 19 years, was severely mentally retarded. He had his first grand mal attack when 15 months old, and had adenoma sebaceum, shagreen plaques, and gingival fibromata. There was a coloboma of the choroid and iris and a retinal phakoma in the right eye.

A sister (III.5 and Table III, A4) was stillborn. Necropsy, however, revealed a rhabdomyoma of the heart, tuberous sclerosis of the brain with 'candle guttering' on the thalamus and the caudate nucleus. The mother's (II.4 and Table III, A8) first grand mal convulsion occurred at 2 years of age, and adenoma sebaceum at 14. She died at 38 years in status asthmaticus, and at necropsy there was tuberous sclerosis of the brain, bilateral renal leiomyomata, and a phakoma of the right eye. All living relatives were examined, but in none was there any evidence of tuberous sclerosis.

(c) Family NN22. The propositus (III.14), a girl of 2 years, had infantile spasms from 4 months. There were no adenoma sebaceum, but on the lower limbs there were multiple depigmented spots. A phakoma was present in the right fundus. The electroencephalogram was abnormal, with extensive multifocal spike and wave abnormalities. Chest and skull $x$-rays and an electrocardiogram showed no abnormality.

A sister (III.15), aged 1 year, also had infantile spasms from 4 months. Her only cutaneous lesion was also multiple depigmented spots on the lower limbs and on the trunk. There were 2 phakomas in the left retina and 2 depigmented patches in the right. The electroencephalogram was abnormal, with varied extensive multifocal spike and slow wave abnormalities. Skull and chest $x$-rays were normal.

The father (II.7), aged 23 years, first noted adenoma sebaceum at 14 years. There was no history of convulsions. He also had shagreen plaques, cervical skin tags, and depigmented spots. Five phakomas were present in the left fundus and 2 depigmented plaques in the right.

The mother (II.8) and all living relatives on the paternal side had no manifestations of tuberous sclerosis.

(d) Family NN9. The propositus (III.1), a woman aged 59 years, had adenoma sebaceum from the age of 5 . She also had shagreen plaques and periungual fibromata of fingers and toes. The fundi were normal. There was no history of convulsions.

A brother (III.6) died at 7 years in a road accident, but according to the propositus he had had epilepsy, adenoma sebaceum, and periungual fibromata of fingers. Another brother (III.7) died aged 28 years with a brain tumour which at necropsy was considered to be an astrocytoma. However, Dr. Oppenheimer of the Neuropathology Department, Radcliffe Infirmary, Oxford, kindly reexamined the cerebral histology, and considered the appearance to be characteristic of the paraventricular tumours of tuberous sclerosis. The necropsy report had also described 'some reddish papules around the mouth'.

The father (II.9) died aged 73 years with emphysem and chronic bronchitis. He had had adenoma sebaceuns but no history of epilepsy. A paternal uncle (II.4) had. an enucleation of the right eye for a malignant melanoma of the choroid. The remaining living relatives were normal. 